\title{
Nancy Atkinson, bacteriologist, winemaker and writer
}

\section{EMMA MCEWIN ${ }^{1}$}

In the last decades of the twentieth century, biographies of Australian women scientists, and articles and book chapters focusing on women's contributions to science during and after World War II began to emerge. Such works seek to acknowledge and highlight the achievements of women in both industry and academia, and to understand how they managed to pursue and negotiate careers in traditionally male-dominated fields. In the first half of last century, women were well represented, both as students and as staff members at many universities in Australia but, while men climbed the career ladder, the majority of women were 'more or less limited to the bottom rungs'.

Yet there were a few exceptions and one was pioneering bacteriologist Nancy Atkinson. A graduate of Melbourne University, Atkinson was appointed lecturer in charge of the Department of Bacteriology at the University of Adelaide in 1942 when she was just 32 years old and was promoted to reader in charge less than a decade later. ${ }^{3}$ In Irresistible Forces: Australian Women in Science, Claire Hooker acknowledges that 'bacteriological research' in Adelaide was 'entirely supported' by Nancy Atkinson and that when she was appointed reader in microbiology at the university, this made her 'the first woman to gain such seniority'. ${ }^{4}$

Atkinson lived through the discovery and successful application of penicillin. In fact, she was the first person to produce penicillin in Australia, ${ }^{5}$ confirming 'its remarkable therapeutic effect in a limited number of cases'. ${ }^{6}$ She also made important contributions to the search for penicillin-like substances that could attack the bacteria of infectious diseases penicillin could not fight, such as tuberculosis,

\footnotetext{
1 The author thanks the peer reviewers for their constructive comments, and the editor for his help. The research was undertaken under a Bill Cowan Barr Smith Library Fellowship, awarded in 2016; special thanks to Lee Hayes and Marie Larsen at Rare Books \& Special Collections, the Barr Smith Library, Adelaide.

2 Claire Hooker, Irresistible Forces: Australian Women in Science (Carlton, Vic.: Melbourne University Press, 2004), 41.

3 'High Post for S.A. Woman', News, 10 November 1949, 1.

Hooker, Irresistible Forces, 127.

'The Making of Penicillin', News (Adelaide), 20 October 1943, 4.

6 Nancy Atkinson, Application for the Chair of Microbiology, University of Adelaide, 20 December 1958, 3, Dr Nancy Atkinson (1910-1999) Papers, MSS 0065, Series 4, Rare Books \& Special Collections, Barr Smith Library, University of Adelaide.
} 
finding a cure for which was her 'great goal'. ${ }^{7}$ Her other main research focus, aside from antibiotics, was salmonellas. As the recognised Australian authority in this field, ${ }^{8}$ she became known as the 'Salmonella queen'.

Born in Melbourne on 9 March 1910, and growing up in St Kilda, Atkinson was the only child of Stella Charlotte and Ralph Arthur Atkinson. Her father was managing director of a stationery company, Newell and Co. In March 1932, at the age of 52 , he died of pneumonia. ${ }^{10}$ She always lamented the fact that he died too early for penicillin to save him, his death occurring only a decade before the first civilian, Anne Sheafe Miller, was successfully treated after she contracted an infection following a miscarriage. ${ }^{11}$ An innately studious child, who was forbidden to do homework because it overstimulated her mind and prevented her from sleeping, ${ }^{12}$ Atkinson excelled at school. Her son, Jonathan Cook, describes her as 'a genius; an all-round person' who had a gift for languages and for mathematics. ${ }^{13}$ She was educated at Oberwyl, a progressive private girls' boarding school in St Kilda, which offered Latin, Greek and mathematics as well as 'the usual subjects for girls' ${ }^{14}$ The granddaughters of Charles Dickens, Violet and Kathleen Dickens, attended this school, ${ }^{15}$ and also Joan Lindsay, author of Picnic at Hanging Rock. ${ }^{16}$ 'Known for its elegance and French culture', Oberwyl was established in 1867 by Madame Elise Pfund, a Swiss art patron whose portrait was painted by Tom Roberts (and later purchased by two sisters from France), and who also founded the Alliance Française in Melbourne. ${ }^{17}$ In 1925 Atkinson was dux of the school, ${ }^{18}$ and in her leaving year

\footnotetext{
7 Atkinson, Transcript of an Interview with 'Neal', 29 April 1946, 3, Series 6, Dr Nancy Atkinson (1910-1999) Papers.

8 Charles Francis Fenner, ed., History of Microbiology in Australia (Canberra: Brolga Press, 1990), 549.

9 'Nancy Atkinson', in 'A Culture of Learned Professionals: Celebrating 50 Years of the Australian Society of Microbiology', special issue, Microbiology Australia 30, no. 3 (2009): 18, accessed 3 July 2017, microbiology. publish.csiro.au/?act=view_file\&file_id=MA09S50.pdf.

10 'Family Notices', Argus, 15 March 1932, 1.

11 Eric Oatman, 'The Drug That Changed the World', P \& S: The College of Physicians \& Surgeons of Columbia University 5, no. 1 (2005), accessed 30 January 2017, www.cumc.columbia.edu/psjournal/archive/winter-2005/ drug.html (site discontinued).

12 Jonathan Cook (son of Nancy Atkinson), Interview with the Author, 17 April 2016.

13 Cook, Interview with the Author.

14 Marjorie R. Theobald, 'Henderson, Isabella Thomson (Isabel) (1862-1940)', Australian Dictionary of Biography, National Centre of Biography, The Australian National University, adb.anu.edu.au/biography/henderson-isabellathomson-isabel-6631/text11423, published first in hardcopy 1983, accessed online 21 November 2016.

15 'Oberwyl (Formerly Etloe Hall)', St Kilda Historical Society, 2005, accessed 30 January 2017, www.skhs.org. au/SKHSbuildings/27.htm.

16 Jenny Brown, 'Grand St Kilda House Oberwyl for Sale, Offering Insight to Melbourne's History', Domain, 24 February 2016, accessed 30 January 2017, www.domain.com.au/news/grand-st-kilda-house-oberwyl-for-saleoffering-insight-to-melbournes-history-20160223-gn044w/.

17 'Oberwyl', St Kilda Historical Society.

18 'School Speech Days: University High School', Argus, 19 December 1925, 20, accessed 9 February 2017, trove.nla.gov.au/newspaper/article/2174600.
} 
she won the Alliance Française prize for French composition. ${ }^{19}$ Newspaper articles tracking her career suggest that she continued with French and that she had also studied German, reading scientific articles published in both languages. ${ }^{20}$

In her book Degrees of Liberation: A Short History of Women at the University of Melbourne, Kelly Farley argues that a woman in the first half of the twentieth century was more likely to pursue a career in science if one or both of her parents were scientific and valued education. ${ }^{21}$ While the first factor did not apply to Atkinson, it seems the second did, for, according to her son, her parents were supportive of her decision to go to university and regarded it as a natural course for her. ${ }^{22}$ She began a science degree at the University of Melbourne in the late 1920s, majoring in chemistry before transferring to bacteriology; at the time, new disciplines were emerging in the biological sciences as a result of Louis Pasteur's research into infectious diseases in the late 1800s. Atkinson entered the university at a unique time for women whose access to science was helped by the small size of the scientific community, which, up until World War II, was not as highly regarded in Australia as in Europe and the United States of America. ${ }^{23}$ The emergence of research institutes in the major states of Australia, initially in Melbourne with the opening of the Walter and Eliza Hall Research Institute in 1915, and soon afterwards in Sydney and Adelaide, as well as the growth of 'medical specialization' brought increased employment opportunities. ${ }^{24}$ The war consolidated women's place in the scientific community and, furthermore, as Jane Carey notes, women were not 'unilaterally pushed out of their jobs at war's end'. 25

Ann Moyal attributes the 'significant movement of women in science' in the early 1900 s to motivation, confidence and opportunities to pursue a career in research, and to the fact that there was 'a niche position captured by women, notably in Melbourne, in the young discipline of microbiology. ${ }^{26}$ Many of the women who graduated in the biological sciences from the University of Melbourne in the 1930s, around the time that Atkinson graduated, went on to have distinguished careers in bacteriology. They include Nancy Hayward, who became a senior lecturer at Monash University, Jean Tolhurst, Hildred Butler and Phyllis Rountree, all of whom went on

19 'University of Melbourne: March Supplementary Annual Examination, 1927', Argus, 1 April 1927, 5, accessed 9 February 2017, nla.gov.au/nla.news-article3846859.

20 'Fills Place for Professor: Important War-Time Post', Mail (Adelaide), 27 June 1942, 6.

21 Farley Kelly, Degrees of Liberation: A Short History of Women in the University of Melbourne (Parkville, Vic.:

Women Graduates Centenary Committee of the University of Melbourne, 1985), 39.

22 Cook, Interview with the Author.

23 Jane Carey, 'Engendering Scientific Pursuits: Australian Women and Science, 1880-1960', Limina: A Journal of Historical and Cultural Studies 7 (2001): 18.

24 Nessy Allen, 'A Pioneer of Paediatric Gastroenterology: The Career of an Australian Woman Scientist', Historical Records of Australian Science 11, no. 1 (1996): 35.

25 Carey, 'Engendering Scientific Pursuits', 18.

26 Ann Moyal, 'Invisible Participants: Women in Science in Australia, 1830-1950', Prometheus 11, no. 2 (1993): 181. 
to hold senior positions in major hospitals. ${ }^{27}$ Dora Lush, a particularly promising microbiologist in the field of bacteriophages and animal viruses, ${ }^{28}$ was not so lucky. After graduating BSc in 1932, ${ }^{29}$ and working with and co-writing a number of papers with Frank Macfarlane Burnet, a leading figure in the development of medical research in Australia and director of the Walter and Eliza Hall Institute from 1944 to 1965 , she died in 1943 of a highly virulent strain of scrub typhus caught from a soldier in north Queensland. ${ }^{30}$ As was the case with Atkinson's father, at the time of Lush's death, medicine was not advanced enough to save her life. Just three years later, chloramphenicol became available to treat scrub typhus, ${ }^{31}$ which, according to Macfarlane Burnet, 'could have prevented even the signs of primary infection'. ${ }^{32}$

When she graduated BSc in 1930, two years before Lush, whom she most certainly would have known, Atkinson became one of the first two students in the country to major in bacteriology. ${ }^{33}$ She graduated MSc a year later. In 1932, supported by a grant, she worked as a research scholar in the Department of Bacteriology investigating pollution in the waters of Port Phillip Bay, and the public's immunity to typhoid and paratyphoid, ${ }^{34}$ which inspired an abiding interest in water bacteriology. Between 1933 and 1937, she worked in the department as a demonstrator in Bacteriology I and Medical Bacteriology and gave practical lectures in Bacteriology II.

In 1937 Atkinson moved to Adelaide after being appointed assistant bacteriologist to Professor Albert Edward Platt at the South Australian Government Laboratory of Pathology and Bacteriology, which was incorporated into the Institute of Medical and Veterinary Science (IMVS) ${ }^{35}$ the following year. When her appointment was announced in the Adelaide News in May 1937, it was explained that her exceptionally high qualifications' had given her 'an advantage over other applicants' . ${ }^{36}$ The IMVS undertook research in clinical medicine and also offered teaching and laboratory services. ${ }^{37}$ Situated in the grounds of the Adelaide Hospital, ${ }^{38}$ it was an extension of the facilities already provided at the hospital for research into human

\footnotetext{
27 Fenner, History of Microbiology in Australia, 252.

28 Fenner, History of Microbiology in Australia, 267.

29 Rasmussen, Carolyn, 'Lush, Dora Mary (1910-1943)', Australian Dictionary of Biography. National Centre of Biography, The Australian National University, accessed 21 April 2017, adb.anu.edu.au/biography/lush-doramary-10874.

30 Fenner, History of Microbiology in Australia, 267.

31 Macfarlane Burnet, Changing Patterns: An Atypical Autobiography (Melbourne: Heinemann, 1968), 80.

32 Macfarlane Burnet, Walter and Eliza Hall Institute, 1915-1965 (Melbourne: Melbourne University Press, 1971), 49 .

33 The other student was Arthur Barclay Jamieson. The University of Melbourne was the first Australian university to offer the subject as a major in a science degree.

34 Elisabeth George, 'Woman's World Round-About', Mail (Adelaide), 29 April 1944, 15.

35 The IMVS is now known as SA Pathology.

36 'Melbourne Woman Given Research Post', News (Adelaide), 29 May 1937.

37 Brendon J. Kearney, 'The Institute of Medical and Veterinary Science', Medical Journal of Australia 167, no. 11 (1997): 614.

38 The Adelaide Hospital was officially renamed the Royal Adelaide Hospital in November 1939, "'Royal Adelaide Hospital" Now', News (Adelaide), 2 November 1939, 9.
} 
and animal pathology, bacteriology and biochemistry, and it collaborated closely with both the University of Adelaide and the hospital. ${ }^{39}$ Atkinson's work at the institute was primarily in the field of medical microbiology, specifically research into the public's immunity to viruses such as influenza, mumps, measles and infantile paralysis, typhoid and typhus fever; this was in keeping with her previous experience in Melbourne, where she had conducted routine tests for the Victorian Department for Public Health. ${ }^{40}$ Every year, 'tens of thousands ${ }^{41}$ of such tests were carried out for the hospital, other hospitals in the state, and for medical and veterinary practices. Atkinson claimed that during her eight years at the IMVS, 'the number of specimens examined totalled about 150,000 ' ${ }^{42}$

In 1939, while still employed at the IMVS, she began working part time as a lecturer at the University of Adelaide, and she continued to work concurrently at the IMVS and the university until $1949 .{ }^{43}$ According to Atkinson, Platt had 'invited' her to be a lecturer at the university in $1938,{ }^{44}$ as a new department of bacteriology was being developed. He had designed the Bacteriology I course, which he had introduced in 1936 following his appointment as lecturer in bacteriology in the Department of Pathology in the medical faculty in 1935. Although he had drafted the syllabus for the more advanced course of Bacteriology II, this was not offered until 1939, the year in which an independent chair and department were created and housed in the new laboratories, which had just opened at the IMVS. ${ }^{45}$

In July 1939 Platt went abroad and did not return until September 1940. During his absence Atkinson took over his roles, becoming both acting head of the department and bacteriologist in charge at the IMVS. In 1941 Bacteriology II was offered for the second time (the intention was to run it only in alternate years) but Platt resigned in September that year, before the course had finished, to take up the position of acting director of the Department of Pathology at Prince Henry Hospital in Sydney. Atkinson was appointed acting head of the department on his resignation, and on Platt's recommendation, although, as explained to Atkinson by the then university

39 Charles Martin, 'The Institute of Medical and Veterinary Science, Adelaide: Opening of New Laboratories', Nature 144, no. 3643 (1939): 392-93.

40 Nancy Atkinson, Letter of Application for the Position of Assistant Bacteriologist at the Laboratory of Bacteriology and Pathology of the South Australian Government, 8 April 1937, Series 5, Dr Nancy Atkinson (1901-1999) Papers.

41 Nancy Atkinson, 'A Collection of Papers on Part 1: "Antibiotics of Australian Plants and Fungi"; Part 2: "Australian Salmonellas and Their Bacteriophages", PhD diss., University of Adelaide, 1956, 1, Series 19, Dr Nancy Atkinson (1910-1999) Papers.

42 Atkinson, Application for the Chair of Microbiology, 2, Series 4, Dr Nancy Atkinson (1910-1999) Papers.

43 Until 1950, it was possible to hold joint appointments at these two institutions. Bernard Nicholson, Institute of Medical and Veterinary Science: 50th Anniversary Review, 1938-1988 (Adelaide: Institute of Medical and Veterinary Science, 1988), 89.

44 Atkinson, Application for the Chair of Microbiology, 2, Series 4, Dr Nancy Atkinson (1910-1999) Papers.

45 Prior to this, as in most universities at the time, bacteriology was part of pathology and controlled by the medical faculty. 
registrar, Frederick William Eardley, he (Platt) had advised against 'any addition' to her salary because a contribution for her 'services' was already being made 'to the funds of the Institute of Medical and Veterinary Science. ${ }^{46}$

In an interview soon after her appointment, Atkinson was quoted as saying, 'I feel that I have a great opportunity ... at the university in taking over the work of the professor, although I realise that it does not fall to a woman's lot to hold the professor's chair' ${ }^{47}$ Later she was to change her mind about this, as indicated in her bid for the newly created chair of microbiology in 1959. In her letter of application, she clearly indicates that she believed that she had by then long since qualified for the role, having carried out 'all the functions of a Professor of Microbiology' for years, despite her status remaining at lecturer level. The department, she argued, had been developed 'entirely' by her own 'personal efforts', for while Platt had 'laid the foundations', he had been absent for ' 15 months out of the two years and nine months that he was Professor'. ${ }^{4}$

In 1942, following Platt's departure, Atkinson taught three subjects: Bacteriology I, Bacteriology II (which was offered again owing to student demand and thereafter offered every year) and Medical Bacteriology with minimal assistance, that is, with only one or two demonstrators. Her position entailed lecturing across four disciplines, for as well as being taught in science and medicine, bacteriology was also a subject in the faculties of Agricultural Science and Dentistry. Although it had traditionally been considered a medical subject (through the study of infectious diseases), Atkinson felt very strongly that much of bacteriology lay just outside the purview of medicine; she believed that it belonged more properly to the Faculty of Science ${ }^{49}$ and designed courses to reflect this. In 1945 she revised and extended Medical Bacteriology to better accommodate dentistry students; in 1946 she designed a bacteriology course for agricultural science students and offered postgraduate courses to medical students. The following year she introduced postgraduate courses for dental students and a bacteriology course for pharmacy students. A decade later, she created a course in industrial microbiology for industrialists and engineers. Summarising her work in the department in her application for the chair of microbiology, she pointed out that she had sacrificed her own research to build a school of microbiology and that her decision to do this had been 'critical in the development of microbiology in the University', adding that, had she not developed science courses, 'microbiology would have been relegated to one or two applied courses'..$^{50}$ Throughout her years in the department, Atkinson campaigned tirelessly for more staff and teaching

\footnotetext{
46 F. W. Eardley, Letter to Nancy Atkinson, 1 December 1938, Series 4, Dr Nancy Atkinson (1910-1999) Papers.

47 'Fills Place for Professor', Mail (Adelaide), 6.

48 Atkinson, Application for the Chair of Microbiology, 2, Series 4, Dr Nancy Atkinson (1910-1999) Papers.

49 Atkinson, Draft of an article entitled 'Bacteriology in the Universities', 1947, Series 4, Dr Nancy Atkinson (1910-1999) Papers.

50 Atkinson, Application for the Chair of Microbiology, 1-2, Series 4, Dr Nancy Atkinson (1910-1999) Papers.
} 
space, and more equipment and maintenance of equipment to accommodate growing numbers of students. She claimed that it was not until 1950, when her responsibilities at the IMVS ended and she was appointed full time at the university as reader in charge of the Department of Bacteriology, that she found the time to devote to her own research. ${ }^{51}$

While teaching and administrative duties took up much of her time at the university, Atkinson was kept busy with routine testing and research at the IMVS. The research work, which was largely funded by annual grants for salaries, focused on antibiotics, salmonellas and other groups of bacteria, bacteriophage and dairy bacteriology, as well as vaccines for tuberculosis and typhoid. On a small scale, in collaboration with medical practitioner Darcy Cowan, physician at the chest clinic at the Royal Adelaide Hospital, ${ }^{52}$ and founder of the South Australian Tuberculosis Association in $1943,{ }^{53}$ she prepared BCG (Bacille Calmette Guerin) vaccine, aimed at preventing tuberculosis. ${ }^{54}$ In the 1940 s the IMVS was the only laboratory producing the vaccine in Australia and carrying out research in this field. Though not strictly a cure, the vaccine acted as a preventative; the ultimate aim was to mass produce it to make it available to all Australians. Atkinson and her team treated batches of volunteers and had some success in suppressing tuberculosis infections. When funding was withdrawn by the federal government in 1949 , the research was discontinued ${ }^{55}$ and the production of the vaccine developed by Atkinson and Cowan was taken over by the Commonwealth Serum Laboratories. ${ }^{56}$

Frank Fenner, a microbiologist and virologist, pointed out that, during World War II, 'in Australia as in other combatant countries much civilian research was focussed on the war effort' ${ }^{57}$ Macfarlane Burnet, who remarked that he would 'always regard the war and the immediate post war period as the time when the full possibilities of control of infectious disease were realized or could be clearly envisaged', ${ }^{58}$ undertook research into influenza immunisation, and his assistant Dora Lush into scrub typhus until her premature death.

51 Atkinson, 'A Collection of Papers', PhD diss., 1-2, Series 19, Dr Nancy Atkinson (1910-1999) Papers.

52 Roger Clare Angrove, '1991-Tuberculosis Control in South Australia', Royal Adelaide Hospital, 1991, accessed 11 November 2017, www.healthmuseumsa.org.au/menu/1991-tuberculosis-control-in-south-australia/.

53 Philip Woodruff, 'Cowan, Sir Darcy Rivers Warren (1885-1958)', Australian Dictionary of Biography, National Centre of Biography, The Australian National University, accessed 11 July 2017, adb.anu.edu.au/biography/cowansir-darcy-rivers-warren-9845, published first in hardcopy 1993.

54 R. L. Worrall, 'New T.B. Director Should Have Widest Powers: Urgent Need for Australia-Wide Overhaul of Methods of Treatment', Australian Women's Weekly, 19 April 1947, 21.

55 'T.B. Vaccine Research: Work Ceases Through Lack of Funds', West Australian, 23 April 1949, 17.

56 Atkinson, Application for the Chair of Microbiology, 3, Series 4, Dr Nancy Atkinson (1910-1999) Papers. Cowan went on to establish the National Association for the Prevention of Tuberculosis sufferers and Bedford Industries, a rehabilitation facility for tuberculosis sufferers; Woodruff, 'Cowan, Sir Darcy Rivers Warren (1885-1958)'.

57 Fenner, History of Microbiology in Australia, 568.

58 Atkinson, 'Letter to the Deputy Vice-Chancellor, University of Adelaide', n.d., Series 4, Dr Nancy Atkinson (1910-1999) Papers. 
At the IMVS, Atkinson and her team worked on antibacterial substances from penicillum mould to help in the prevention of bacteria in war wounds, as well as carrying out research into gastrointestinal infections and food poisoning. ${ }^{59}$ She trained medical students to work for the pathology department of the Army Medical Corps and coordinated a course preparing bacteriologists to work in military hospitals, in which they would advise doctors in their diagnoses. ${ }^{60}$ In 1942 , one of her demonstrators, Joyce Hammill, née Gemmel Tassie, became the first student from the department to take up a military post, along with Madeleine Angel of the Department of Zoology. ${ }^{61}$ Hammill was given the rank of lieutenant.

As at the Walter and Eliza Hall Institute in Melbourne, the IMVS undertook research on influenza. In anticipation of another flu epidemic like that experienced in World War I, many scientists were working on developing vaccines, including Jessica Mawson, younger daughter of Douglas Mawson, the Antarctic explorer and professor of geology (1921-52) at the University of Adelaide. Jessica, who transferred from botany to bacteriology at her father's suggestion, and who had majored in bacteriology under Atkinson in the first year it was offered, was Atkinson's sole assistant in the Department of Bacteriology in 1939 when Platt was on leave and continued to work as a research assistant and demonstrator at both the IMVS and the university throughout World War II. In 1942 she became the first person in South Australia to isolate an influenza virus strain ${ }^{62}$ using a technique she had learnt from Macfarlane Burnet, which entailed taking the virus directly from humans and growing it in chick embryos. ${ }^{63}$ In 1944 , in collaboration with another assistant, Charles Swan, she mounted a live influenza vaccine trial using isolated cultures from Macfarlane Burnet. ${ }^{64}$ Fortunately the world avoided a repeat of the epidemic of World War I.

59 'Fills Place for Professor', Mail (Adelaide), 6.

60 Elisabeth George, 'Vital War-time Role Played by Our University', Mail (Adelaide), 10 October 1942, 5.

61 George, 'Vital War-Time Role Played by Our University', 5.

62 Bernard Nicholson, ed., Institute of Medical and Veterinary Science: 50th Anniversary Review, 1938-1988

(Adelaide: Institute of Medical and Veterinary Science, 1988), 89.

63 Fenner, History of Microbiology in Australia, 342.

64 Nicholson, Institute of Medical and Veterinary Science, 89. 


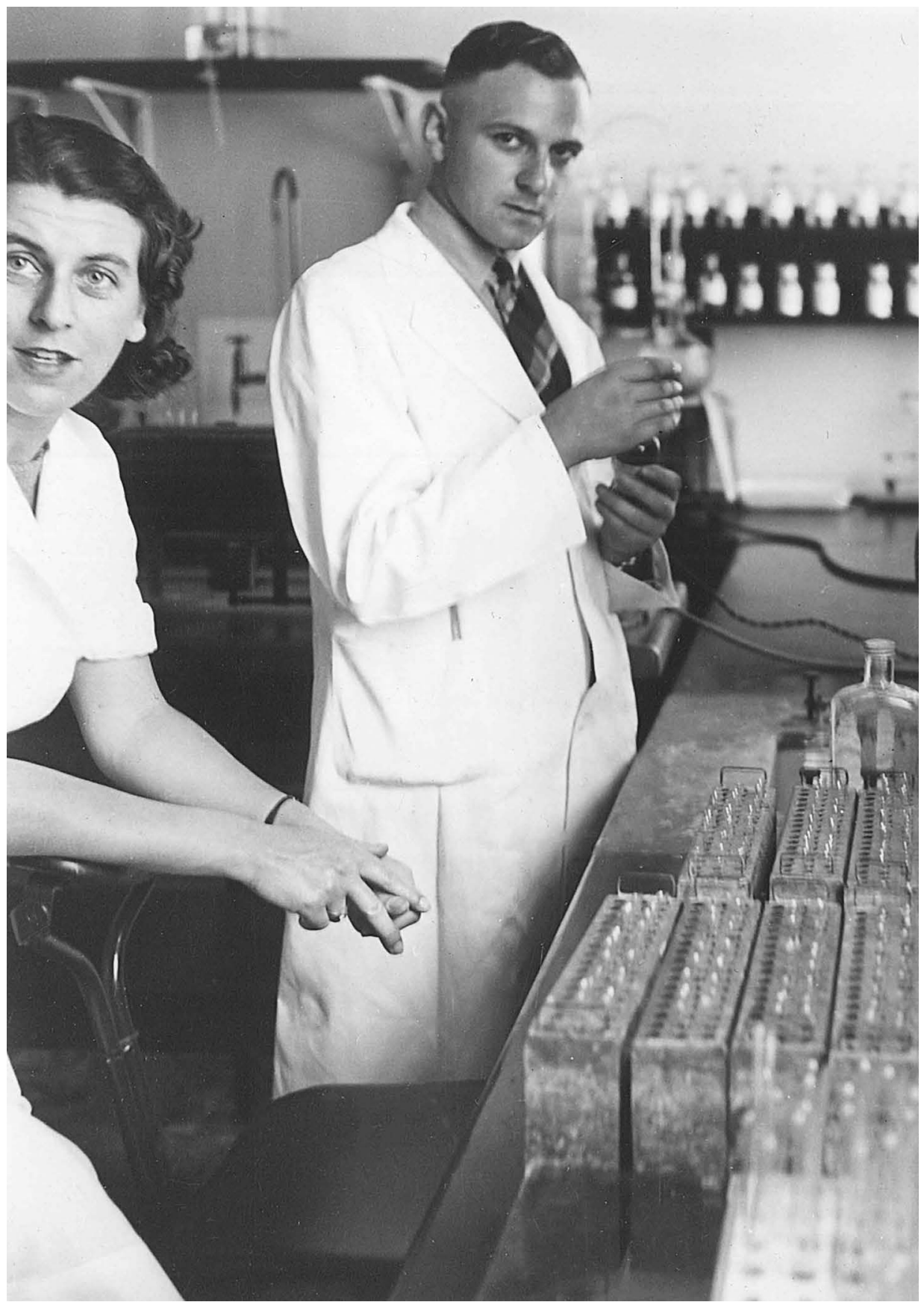

Figure 1: Nancy Atkinson, probably at the IMVS, with a research assistant, Martin Hansen, c. 1939.

Source: Dr Nancy Atkinson (1910-1999) papers, MSS 006, 5, Series 2. Courtesy of Rare Books \& Special Collecitons, Barr Smith Libray, University of Adelaide. 
The then director of the IMVS was an Englishman, Edward Weston Hurst. Well known for his research in neuropathology and virus diseases, he inspired Atkinson's interest in antibiotics and early research into antibiotics in moulds ${ }^{65} \mathrm{Her}$ investigations led to the isolation of a new antibiotic, 'penicidin', ${ }^{66}$ which turned out to be identical to several other mould antibiotics discovered in England and the United States at around the same time. Claviformin was the first mould antibiotic to be characterised and Atkinson's penicidin was identified with claviformin by Howard Florey, who took samples of her penicidin crystals to England for analysis after a visit to Adelaide in $1944 .{ }^{67}$ She did not, however, undertake any further research into mould antibiotics, judging that the field 'seemed already overcrowded'. ${ }^{68}$

Florey encouraged Atkinson to undertake research into antibacterial substances in fungi, arguing that she was in a unique position to undertake such a study at the University of Adelaide because John Cleland, professor of pathology from 1920 to 1948 (whose daughter, Joan Cleland, later Paton, was the first appointed biochemist at the IMVS), was an authority on classifying fungi. Cleland agreed not only to help Atkinson with identification but also with the collection of fungi on excursions into the Adelaide Hills. ${ }^{69}$ In response to appeals in the local paper for plant and fungi samples, members of the public scoured their gardens and the city parklands for specimens, which they delivered to the gates of the institute on Frome Road. ${ }^{70}$ Toadstools and mushrooms, as well as hundreds of kinds of flowering plants, many from the garden of the botanical artist and plant collector Alison Ashby, ${ }^{71}$ were collected and tested. Among those tested, the Geraldton wax and Lepidium showed the most promising results; ${ }^{72}$ of the small number of fungi specimens found to contain antibacterial substances, most were only active against the same diseases as penicillin. However, a substance found in the 'umbrella part' of 'a rare edible mushroom, Psalliota xandthoderma', ${ }^{73}$ proved effective in killing (in the test tube), a wide range of disease germs unaffected by penicillin, including typhoid and tuberculosis germs; additionally, these germs had not acquired resistance, unlike penicillin and streptomycin. ${ }^{74}$ Atkinson's research later expanded to include testing of dried plant specimens obtained from northern Australia and New Guinea, and the investigation of antibacterial substances in essential oils from native Australian plants, a field in which little had been published.

65 Atkinson, 'A Collection of Papers', PhD diss., 3, Series 19, Dr Nancy Atkinson (1910-1999) Papers.

66 'SA Scientist Finds New Drug', Telegraph (Brisbane), 2 April 1943, 2.

67 Atkinson, 'A Collection of Papers', PhD diss., 3, Series 19, Dr Nancy Atkinson (1910-1999) Papers.

68 Atkinson, 'A Collection of Papers', PhD diss., 1, Series 19, Dr Nancy Atkinson (1910-1999) Papers.

69 Atkinson, 'A Collection of Papers', PhD diss., 3-4, Series 19, Dr Nancy Atkinson (1910-1999) Papers.

70 'Woman Scientist's [sic] as Bacteriologist', Advertiser (Adelaide), 5 December 1945, 3.

71 Atkinson, 'A Collection of Papers', PhD diss., 4, Series 19, Dr Nancy Atkinson (1910-1999) Papers.

72 'Flowers May Give New Penicillin', Barrier Miner, 19 October 1944, 6.

73 Atkinson, 'Anti-Bacterial Substances in Australian Plants and Fungi', Clinic, July 1946, 2, Series 12, Dr Nancy Atkinson (1910-1999) Papers'.

74 'Mushroom Drug Checks T.B'., Truth (Sydney), 29 May 1949, 46. 
At the same time, Atkinson pursued research into salmonellas, an interest that had started when she was working at the University of Melbourne and the senior lecturer, Thomas Screen Gregory, got her to make some salmonella antisera. ${ }^{75}$ She had taken this salmonella to Adelaide and later sourced samples from other institutes. ${ }^{76}$ In the 1940 s and '50s her focus was on identifying strains of Salmonella gastroenteritis in Australia, outbreaks of which in the first half of the twentieth century were 'extremely common' and sometimes life-threatening. ${ }^{77}$ Little research had been done on humans as carriers because it was thought that animals were the primary source of food poisoning. ${ }^{78}$ Assisting her in investigating cases of gastroenteritis in South Australia were Gwendolyn Woodroofe, who, in 1943, was the first of Atkinson's students to graduate MSc in bacteriology; Maureen Macbeth, daughter of Alexander Killen Macbeth, chair of chemistry at the university from 1928 until 1954; and Jessica Mawson. The four women were described as 'the strongest team yet' to undertake such research, ${ }^{79}$ which was carried out at a salmonella typing laboratory established by Atkinson. The laboratory was the first of its kind in the country, and one of only three in the world at the time capable of describing serotypes of this disease; many new ones were described, the most well known being Salmonella adelaide, first isolated in 1943 from a fatal case of enteritis. ${ }^{80}$ In the same year, in collaboration with staff at the Adelaide Children's Hospital, Atkinson isolated, for the first time in South Australia, S. typhi-murium, commonly known as 'mouse typhoid', a leading 'cause of gastro-enteritis'. ${ }^{81}$ The laboratory sourced salmonella cultures from both humans and animals Australia wide, including from army hospitals as there were frequent salmonella outbreaks among troops. A severe outbreak in New Guinea and on Bougainville led to the isolation of a rare type, $S$. belgdam..$^{82}$ Fenner noted that Atkinson's research interests 'extended well beyond the serological identification of salmonellae' to recognising 'the potential benefits of phage typing in epidemiological studies of outbreaks' ${ }^{83}$

In $\mathrm{ABC}$ radio interviews, articles for popular magazines and talks to local societies such as church groups, rotary clubs and public libraries, Atkinson educated the public about the dangers of pathogenic bacteria. She advocated precautions to eliminate the risk of salmonella infections; on a community level, she advised inspecting meat, exterminating rats and mice, pasteurising milk and ensuring the water supply was to a high standard. On an individual level, she recommended storing food, so that

75 Atkinson, 'A Collection of Papers', PhD diss., 6, Series 19, Dr Nancy Atkinson (1910-1999) Papers.

76 Fenner, History of Microbiology in Australia, 236.

77 Fenner, History of Microbiology in Australia, 237.

78 Atkinson, 'Food Poisoning and the Salmonellas', typed draft, Series 6, Dr Nancy Atkinson (1910-1999) Papers.

79 Elisabeth George, 'Woman's World: Round-About', Mail (Adelaide), 29 April 1944, 15.

80 Nancy Atkinson, 'A New Salmonella Type: Salmonella Adelaide', Australian Journal of Experimental Biology and Medical Science 21, no. 3 (1943): 171-73.

81 'Control of Food Urged: Expert Also Seeks Notification of Gastro-Enteritis', News (Adelaide), 11 January 1943.

82 Atkinson, 'Food Poisoning and the Salmonellas', Dr Nancy Atkinson (1910-1999) Papers.

83 Fenner, History of Microbiology in Australia, 237. 
rats, mice and flies could not contaminate it, and keeping it cold, but also heating it sufficiently before consumption. She warned that tuberculosis, a common disease in cows, could be contracted by drinking milk. If a cow had mastitis, it could introduce bacteria into the milk that could lead to a number of diseases, including diphtheria, scarlet fever, typhoid, acute gastroenteritis or septic sore throat. If the milk were kept at a warm temperature for a period of time, this could also lead to disease. ${ }^{84}$ Fearing a milk-borne epidemic as a result of unpasteurised milk, ${ }^{85}$ in the mid-1940s she carried out tests for the Metropolitan Board of South Australia on the quality of milk, cream and ice cream to assess their suitability for human consumption, and tested penicillin on cows suffering from mastitis, which proved highly effective. Her research led to the establishment of the Metropolitan Milk Board in 1946 to standardise the production, sale, storage and delivery of milk. ${ }^{86}$

Soon after moving to Adelaide, Atkinson had met Irving MacDonald Cook whom she married at St John's Church, Halifax, on 24 January $1942 .{ }^{87}$ A trained architect who had been unable to find work after graduating, Cook had gone into the cinema business like his father, later becoming the South Australian manager of British Empire Films. ${ }^{88}$ As Claire Hooker notes, for women, 'matrimony was regarded as a profession in itself'. ${ }^{89}$ Yet, while marriage could have ended her career as it had and would for so many other women, it did not for Atkinson. In a newspaper article a few years into her marriage, she was described as 'belonging to that relatively small number of women who have proved themselves capable of combining two careers successfully'. The 'two careers' included her work as an academic and her role as Mrs Irving Cook, 'first rate cook and housekeeper'. ${ }^{90}$ Undoubtedly it helped that Cook was supportive of her career. In an interview on 29 April 1946 she said, 'my husband is quite willing for me to continue my work here'. ${ }^{91}$ In 1948 they had a son, Jonathan, and before he was a year old Atkinson returned to work and soon afterwards embarked on a research trip. She had been granted leave of absence from the university to travel to the United States, Britain and Denmark over the summer vacation of 1949-50. She visited the medical school at Stanford University, where she had been invited as an exchange visitor to work with the American geneticist Joshua Lederberg on the immunogenetics of salmonellas. ${ }^{92}$ Lederberg later won (in 1958) a Nobel Prize for his research on bacterial genetics. ${ }^{93}$

\footnotetext{
84 Atkinson, 'Milk', draft of an article, Series 6, Dr Nancy Atkinson (1910-1999) Papers.

85 'Milk-Borne Epidemic “Constant Danger”', News (Adelaide), 22 August 1949, 1.

86 'Milk-Borne Epidemic "Constant Danger", News (Adelaide).

87 Newspaper Clipping of Marriage Notice, Series 1, Dr Nancy Atkinson (1910-1999) Papers.

88 'Visit of Film Company Manager', Border Watch (Mount Gambier, SA), 2 January 1947, 1.

89 Hooker, Irresistible Forces, 44.

90 'Woman Scientist's [sic] as Bacteriologist', Advertiser (Adelaide).

91 Atkinson, Transcript of an Interview with 'Neal', Series 6, Dr Nancy Atkinson (1910-1999) Papers.

92 Cook, Interview with the Author.

93 'Joshua Lederberg: American Geneticist', Encyclopaedia Britannica, 19 May 2018, accessed 14 June 2018, www.britannica.com/biography/Joshua-Lederberg.
} 
Also included in Atkinson's research program was the study of the latest developments in polio research, which involved visiting research institutes as well as university departments to investigate teaching methods. Copenhagen was where one of the three salmonella reference libraries was located; the others were her own in Adelaide and one in London. ${ }^{94}$ Having carried out research into milk-borne diseases and how to safeguard against them since the early 1940s, she also visited dairy farms in New York State and California to observe milk standards. She was impressed with what she saw in the United States and Britain, where even small farms were equipped with coolers and where milk was bottled before it was pasteurised. ${ }^{95}$

A few months after her return, a polio research laboratory was opened at the medical school in the university. ${ }^{96}$ Under Atkinson's guidance and funded by a government grant, tests were carried out on baby mice injected with specimens of the virus obtained from patients suffering from a polio epidemic in the late 1940s, in the first cases of polio in Australia. ${ }^{97}$ In 1950 her marriage to Irving Cook ended amicably. Their son recalls his parents shared an interest in tennis (they had met at a tennis party) but were otherwise 'diametrical opposites'. ${ }^{98}$ Yet, Atkinson's divorce from Cook had no effect on her career. The next year she was appointed OBE for her contributions to public health; she also began a $\mathrm{PhD}$ based on the research on plants and fungi she had undertaken during the war and immediate postwar years while working as head of both the IMVS and the Department of Bacteriology at the university.

The following year she married Hungarian-born Andrew Benko, whom she had met while Cook was away on business in Hollywood. Like Cook, Benko had trained as an architect, and had obtained his doctorate in Milan. A practising architect and a town planner, he was also, according to Jonathan Cook, 'highly academic' and, therefore, a better match for Atkinson. ${ }^{99}$ The Benkos shared an appreciation for art and classical music, and enjoyed playing golf and taking annual trips to the Victorian snowfields. Jonathan, who remembers going to the snow with them sometimes, and recalls once having to drive home from Falls Creek in their tiny Ford Anglia after their chalet burnt down, admired them for being 'total stalwarts' despite being 'absolutely hopeless' at both skiing and golf. ${ }^{100}$

\footnotetext{
94 Atkinson, 'The Salmonella Group of Bacteria', n.d., 15-16, Series 13, Dr Nancy Atkinson (1910-1999) Papers. 95 'Lessons on Treating SA Milk Seen on Trip', Mail (Adelaide), 8 April 1950, 33.

96 'Polio Laboratory Inspected', Advertiser (Adelaide), 17 June 1950, 5, Series 2, Dr Nancy Atkinson (1910-1999) Papers.

97 'New Type of Virus Discovered in SA: Polio Research Heartening', News (Adelaide), 21 December 1950, 4, Series 2, Nancy Atkinson (1910-1999) Papers.

98 Cook, Interview with the Author.

99 Atkinson, Application for the Chair of Microbiology, 'Appendix 1: Record of Positions Held, Duties and Responsibilities and Research Work', Series 4, Dr Nancy Atkinson (1910-1999) Papers.

100 Cook, Interview with the Author.
} 
Just as neither a divorce nor having a child had derailed her career, a second marriage proved no hindrance either, as 1952 was also the year that Atkinson was appointed reader in charge of the Department of Bacteriology. Her research projects continued; she qualified for her DSc with distinction in 1957 and in 1958 she introduced a new course in chemical technology. Advertised as 'a specialist course for food technologists', it was aimed at students interested in working in the food or dairying industries. ${ }^{101}$ By this time, many of her students were enjoying successful careers. While Jessica Mawson had not continued work after her marriage in the mid-1940s, Atkinson's first MSc student, Gwendolyn Marion Woodroofe, had joined the John Curtin School of Medical Research in Canberra in 1951, where she worked as a research assistant to Fenner on myxomatosis. ${ }^{102}$ Neville Fenton Stanley, a 1942 graduate who had worked as a demonstrator for Atkinson in 1943, had gone to work under Platt at the Prince Henry Hospital, probably at Atkinson's recommendation, where he was later promoted to bacteriologist and senior research officer. ${ }^{103}$ In 1948 Platt died suddenly at the age of $48 .{ }^{104}$ At the time he was director of the Institute of Epidemiology and Preventative Medicine. Stanley was appointed acting director on his death and became director in $1954 .{ }^{105}$ In taking over these joint positions initially held by Platt, and starting off in the role of assistant bacteriologist, Stanley's career route almost mirrored that of Atkinson's when she had replaced Platt at the University of Adelaide and at the IMVS a decade before, except that Stanley's career took flight-by the mid-1950s, he was foundation professor of microbiology in the medical school of the University of Western Australia ${ }^{106}$ - while Atkinson's came to a halt.

101 W. F. Nicholas (Secretary Food Technology Association of South Australia), 'Special Notice to All Member Companies Re: Degree Course-Bachelor of Technology', 13 January 1958, Series 8, Dr Nancy Atkinson (19101999) Papers.

102 Maggie Shapley, 'Woodroofe, Gwendolyn Marion (1918-2012)', Australian Women's Register, 20 February 2013, accessed 14 June 2018, www.womenaustralia.info/biogs/AWE4881b.htm.

103 R. B. Lefroy, 'Stanley, Neville Fenton (1918-1984)', Australian Dictionary of Biography, National Centre of Biography, The Australian National University, accessed 11 November 2016, adb.anu.edu.au/biography/stanleyneville-fenton-15539, published first in hardcopy 2012.

104 'Sudden Passing of Professor A. E. Platt', Narracoorte Herald, 12 April 1948, 1.

105 Lefroy, 'Stanley, Neville Fenton (1918-2012)'.

106 Lefroy, 'Stanley, Neville Fenton (1918-2012)'. 


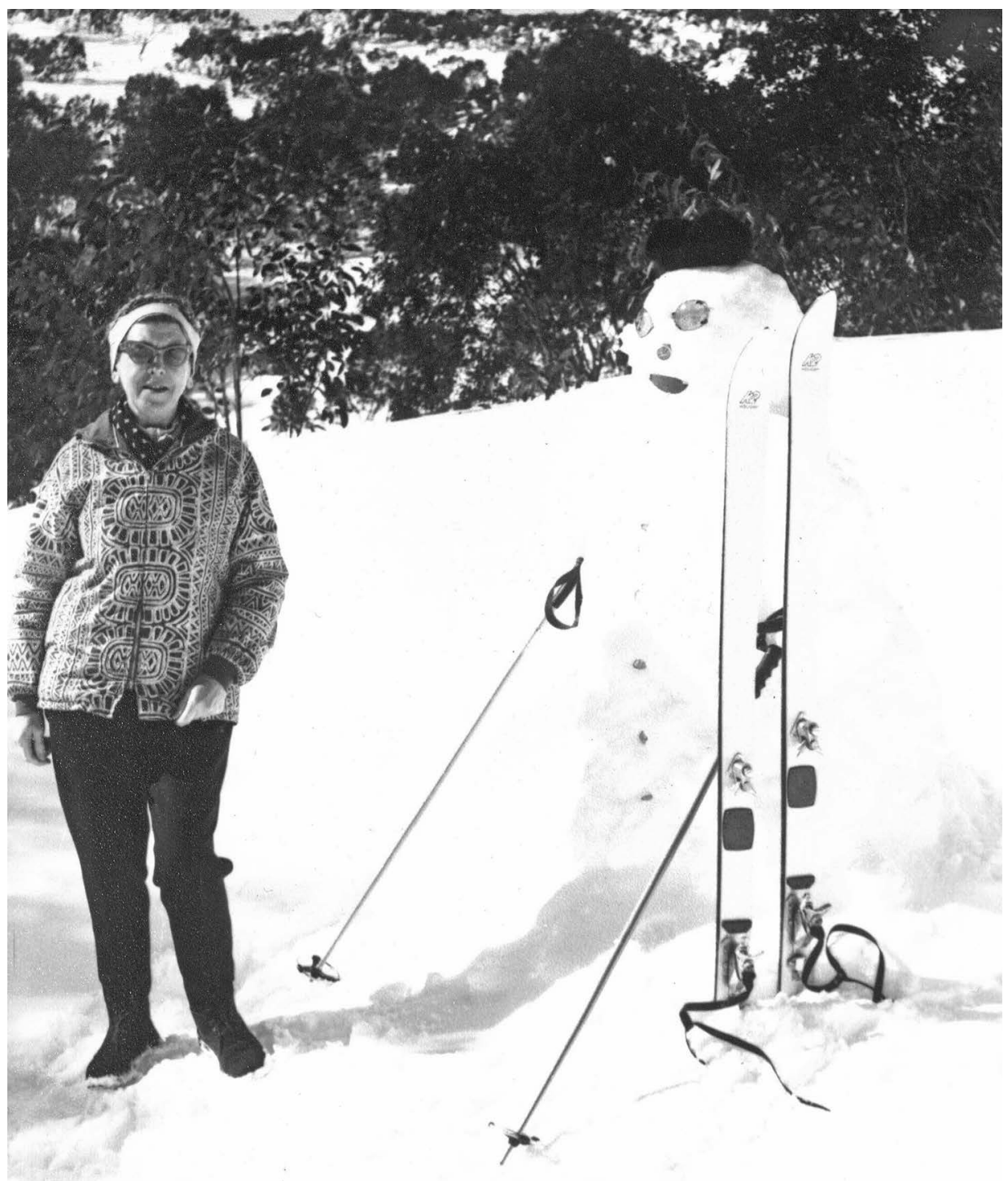

Figure 2: Nancy Atkinson at Falls Creek.

Source: Jonathan Cook. 
In the summer of 1959, arguably at the height of her career, she applied for the chair of microbiology at the University of Adelaide. 'Senior lectureships', notes Moyal, were 'the exceptional woman's glass ceiling', ${ }^{107}$ and this proved true for Atkinson who did not get further than the short list. The position was offered to the microbiologist and immunologist Derrick Rowley, who had worked with Alexander Fleming at the Glaxo Laboratories in London. ${ }^{108}$ The reasons for Atkinson's failure to secure the position are not clear. Her son suspects it was because his mother did not have a medical degree, ${ }^{109}$ unlike Rowley. There was also the fact that Rowley was British, which very likely worked in his favour. In a similar case, Dr Wilfrid Agar had been offered the chair of biology at the University of Melbourne in 1919 over Dr Georgina Sweet, a leading Australian parasitologist. Like Atkinson, who had been in charge of the bacteriology department in Adelaide for almost two decades when Rowley was appointed chair, Sweet had 'more or less run the [biology] department very successfully, for years'. ${ }^{110}$ Like Rowley, Agar was British and, as Claire Hooker argues, he was chosen because Britain was seen as "the centre" of research'. ${ }^{111}$

Atkinson's gender was also undoubtedly a contributing factor. Certainly, other women academics had missed out on chairs because of sexual bias, most notably Ethel MacLennan, Sweet's protégé, who was unsuccessful in her bid for the chair of botany at the University of Melbourne in 1937 despite having an international reputation for her research in mycology (plant fungi) and extensive teaching experience. The then professor of botany, Alfred Ewart, admitted that he had not recommended her 'simply due to the fact that she [was] a woman'. ${ }^{112}$ Would a man in the same position, and with her credentials, have been so quickly overlooked? It was not until 1978, two decades after Atkinson's application for the chair, and three years after her retirement, that the first woman chair was appointed at the University of Adelaide (Fay Gale in geography). ${ }^{113}$

Despite conceding that Rowley was a good appointment, Atkinson's former students recall that there was a general sense in the university that she should have got the position. She certainly took the rejection badly. After nearly two decades running the department without official recognition as the only person in charge (year after year in the university calendar, the role of professor had been left poignantly blank in the space above her name), she found it difficult to accept a man 12 years her junior taking over the department she had built up virtually single-handedly. 'She could

107 Moyal, 'Invisible Participants: Women in Science in Australia'.

108 'Obituary: Derrick Rowley (1922-2004)', Adelaidean, October 2004, accessed 15 August 2016, www.adelaide. edu.au/adelaidean/issues/7082/news7101.html.

109 Cook, Interview with the Author.

110 Hooker, Irresistible Forces, 51.

111 Hooker, Irresistible Forces, 52.

112 Hooker, Irresistible Forces, 56.

113 Nick Harvey, 'Obituary: Fay Gale AO', Adelaidean, June 2008, accessed 17 November 2016, www.adelaide. edu.au/adelaidean/issues/27061/news27160.html. 
not cope with Rowley', recalls Lizzie Rogers, a former student of Atkinson's. ${ }^{114}$ When Rowley was appointed, Atkinson did not go into the department for some weeks until Rowley was compelled to move her things out of her office, which had become his on appointment as the new head. ${ }^{115} \mathrm{He}$ removed her things into 'a kind of storage room', which she complained was too small. She was later moved to a bigger room on the floor above, near her lab. ${ }^{116}$ From then on, according to Ieva Kotlarski, who went on to become a senior lecturer in the department, Atkinson was 'sort of marginalised', but this was partly her own doing. ${ }^{117}$ According to Rowley's wife, Atkinson was resentful towards her husband and they never got along. ${ }^{118}$ It may have come as a relief to Atkinson and to others when, in 1967, she moved to the Department of Oral Biology after the teaching of microbiology to dental students was taken over by this department. She was to remain there until her retirement in $1975 .{ }^{119}$

It seems that, despite this setback, Atkinson's dedication to her work did not diminish. A student and assistant to Atkinson, Anne Moten, who described her as 'very nice to work for' and someone who 'never treated you as lowly', remembers her being 'very keen on her research'. ${ }^{120}$ At around the time of her application for the chair, Atkinson became involved in the formation of the Australian Society of Microbiology. In fact, according to Fenner, it was 'largely due to the enthusiasm and drive of Nancy Atkinson ... that an Australian Society for Microbiology was established'. ${ }^{121}$ At the Australian and New Zealand Association for the Advancement of Science (ANZAAS) congress in Adelaide in 1958, she convened a meeting of about 50 scientists to discuss the idea of a society dedicated to the promotion and fostering of microbiology in Australia with a branch in every state. As the discipline had grown, she argued that there was a need for a forum focused on current research and the exchange of knowledge and ideas specifically related to microbiology rather than to science in general like the ANZAAS. ${ }^{122}$ Atkinson was appointed, along with Jack Harris of the CSIRO and Lance Walters of the SA Brewing Company, to draft a constitution. ${ }^{123}$ She was the first honorary treasurer from 1959 to 1962 , served as president from 1962 to 1964 and was later made an honorary life member. Her legacy is regularly acknowledged by the society; every annual scientific meeting is traditionally opened with the 'Nancy Atkinson Bell'. ${ }^{124}$

114 Lizzie Rogers (former student of Nancy Atkinson), Interview with the Author, 19 November 2016.

115 Ieva Kotlarski (former student of Nancy Atkinson), Interview with the Author, 3 September 2016.

116 Kotlarski, Interview with the Author.

117 Kotlarski, Interview with the Author.

118 Betty Rowley (wife of Derrick Rowley), Interview with the Author, 14 August 2016.

119 Fenner, History of Microbiology in Australia, 37.

120 Anne Moten, Interview with the Author.

121 Fenner, History of Microbiology in Australia, 519.

122 'Chapter One: The Need for a Learned Society: Building a Community', in 'A Culture of Learned Professionals: Celebrating 50 Years of The Australian Society of Microbiology', special issue, Microbiology Australia 30, no. 3 (2009): 14.

123 'Chapter One: The Need for a Learned Society: Building a Community', Microbiology Australia, 15.

124 'Introduction: The Beginnings of a Society', Microbiology Australia, 8. 
While still working full time as an academic, she wrote two books on art under her married name, Benko. The first, Art and Artists of South Australia, was an A-Z of South Australian artists, galleries, schools and events. She was a private art collector and, as she explains in her introduction, the book had developed 'out of a personal interest' in South Australian art and artists and a desire to inspire greater appreciation of the state's art. ${ }^{125}$ Influential people in the art world helped her to compile it. It was written under the guidance of the artists Ruth Tuck and Ivor Francis, and published in 1969 under the patronage of the Latvian father and son, Karlis and Andris Lidums, the directors of a gallery of modern art at Beaumont, Adelaide. As the first book to cover the subject of South Australian art and artists, it was an invaluable resource for art dealers and collectors and remains an important reference source, providing the only available biographical information on many of the artists listed. Atkinson's biography of David Boyd, the figurative painter and potter, The Art of David Boyd, was published in 1973. It was the first biography of Boyd, the lesser-known brother of Arthur Boyd. Andrew Benko designed the book and sourced the details for the illustrations. Judith Wright wrote a foreword and the Lidums were again involved, having suggested the book and supported its publication. A few years later, Atkinson wrote a biographical entry for the Australian Dictionary of Biography on the English-born artist Gustave Barnes, who settled in Adelaide and later became the art supervisor at the Art Gallery of South Australia. ${ }^{126}$

Atkinson's interest in art was, according to her son, largely inspired by her husband. She had begun collecting in the 1960s when she and Benko would go to exhibitions and buy paintings by well-known Australian artists. Among others, works by Pro Hart, David Hesling and Sidney Nolan covered the walls of their North Adelaide home. As her son recalls, there was even 'an antipodean head' by Nolan in their bedroom. ${ }^{127}$ In the late 1970s, however, she had to sell one of her Pro Hart's, The Geebung Polo Club, when her winery proved more expensive than she had anticipated. ${ }^{128}$ This was Chalk Hill Winery, which she had bought in 1973, two years before her retirement. She had begun to plan a winery in the early 1970 s in the knowledge that on her 65 th birthday she would be forced to retire, a prospect that devastated her. ${ }^{129}$ It was important to have something to look forward to and she had developed an interest in winemaking through her course in food technology, which had brought her into contact with brewers and winemakers. She also saw it as a way of applying her knowledge of chemistry. 'Chalk Hill' was in McLaren Vale on 42 acres of land on which there were vineyards and an almond orchard.

125 Nancy Benko, Art and Artists of South Australia (Adelaide: Lidums Family, 1969), 7-8.

126 Nancy Benko, 'Barnes, Gustave Adrian (1877-1921)', Australian Dictionary of Biography, National Centre of Biography, The Australian National University, accessed 14 June 2018, adb.anu.edu.au/biography/barnesgustave-adrian-5137, published first in hardcopy 1979.

127 Cook, Interview with the Author.

128 Cook, Interview with the Author.

129 Cook, Interview with the Author. 
Benko had designed the buildings; he also greeted customers at the cellar door while Atkinson made the wine. They were both quite small physically. Locals recall him barely clearing the counter at the cellar door ${ }^{130}$ and Atkinson (or Nancy Benko as they knew her) sitting so low down in her red Volvo that she had to peer through the steering wheel. She made a variety of wines_riesling, rosé, vintage and tawny port, shiraz, cabernet sauvignon, mead and sparkling mead-and won several prizes: bronze medals for her 1978 rosé and ruby red port; in the same year, silver medals for her vintage port and muscat; and, for several years running in the late 1970s, gold and silver medals for her shiraz. ${ }^{131}$ The winery was open seven days a week and she and Benko would drive there every day. On one occasion, Jonathan visited them on their return from Chalk Hill to find them both 'completely purple'. A wine tank had overflowed and they had been engulfed by 'a tidal wave of red wines and skins' ${ }^{132}$

By the time they sold the winery to the Harveys in 1995, who still own Chalk Hill, Atkinson had begun to suffer from dementia as her mother had. Locals, who had been interested in buying the winery, and who had been half promised it by her, were surprised when they drove past Chalk Hill and saw the 'sold' sign on the road. Andrew Benko had taken an instant shine to the Harveys and made a quick sale, and Atkinson had presumably forgotten any promises she had made. ${ }^{133}$ Four years later, on 21 December 1999, she died, two years after her husband. While she had run Chalk Hill Winery for more than a decade and gained much pleasure from it, and a measure of success, she was, at heart, an academic, and one wonders what else she might have achieved had she not been forced to retire from the university. Even those students who had little to do with her knew that she was 'someone important in the university, who was doing important research work'. Her son acknowledges that she 'probably paved the way for other women'. ${ }^{134}$ Certainly, her dedication to science was indisputable; this struck me when I came across a last will and testament in a box of her belongings at Chalk Hill. Dated 29 October 1940, it was written when she was 30 and new to Adelaide. In it she bequeaths all her 'personal belongings' to Jean Lockhart Sutherland, who had graduated MSc in bacteriology in the same year as Atkinson at the University of Melbourne, and all her 'real estate and money' to the IMVS, 'to be used for the purpose of medical research'.

130 John and Diana Harvey, Interview with the Author, 3 October 2016.

131 Nancy Benko, Miscellaneous Papers, Chalk Hill Winery.

132 Cook, Interview with the Author.

133 Jock Harvey, Interview with the Author, 26 September 2016. Cook, Interview with the Author.

134 Cook, Interview with the Author. 
This text is taken from Australian Journal of Biography and History: No. 1, 2018, published 2018 by ANU Press, The Australian National University, Canberra, Australia.

doi.org/10.22459/AJBH.2018.03 